Article

\title{
Multi-Criteria Decision Model for the Selection of Suppliers in the Textile Industry
}

\author{
Chia-Nan Wang ${ }^{1, *}$, Van Tran Hoang Viet ${ }^{1, *}$, Thanh Phong Ho ${ }^{2}$, Van Thanh Nguyen ${ }^{2}$ \\ and Viet Tinh Nguyen ${ }^{2}$ \\ 1 Department of Industrial Engineering and Management, National Kaohsiung University of Science and \\ Technology, Kaohsiung 80778, Taiwan \\ 2 Department of Logistics and Supply Chain Management, Hong Bang International University, \\ Ho Chi Minh 723000, Vietnam; phonght@hiu.vn (T.P.H.); thanhnv@hiu.vn (V.T.N.); tinhnv@hiu.vn (V.T.N.) \\ * Correspondence: cn.wang@nkust.edu.tw (C.-N.W.); vanviet@tnut.edu.vn (V.T.H.V.)
}

Received: 22 May 2020; Accepted: 5 June 2020; Published: 8 June 2020

check for updates

\begin{abstract}
In recent years, the market of textile and garment materials has been volatile, and the ongoing US-China trade war is creating good opportunities for other markets such as Vietnam, Bangladesh and Mexico to continue to expand their market share in the United States. Vietnam is expected to have great advantages thanks to cheap labor cost and strong production capacity. Raw material supplier selection in a volatile competitive environment is crucial for a company to succeed, and supplier selection is a complicate process in which decision-makers must consider multiple quantitative and qualitative features, along with their symmetrical impact, in order to achieve an optimal result. The purpose of selecting the right supplier is to improve competitiveness and product quality, while satisfying customer demand at a minimum production cost. The aim of this paper is to propose a multicriteria decision making model (MCDM) for garment and textile supplier selection. In the first stage, all criteria affecting this process are defined by using the supply chain operations reference model (SCOR) and experts' opinion. Incorporating hybrid fuzzy set theory into the analytical network process (ANP) model is the most effective tool for addressing complex problems of decision-making, which has a connection with various qualitative criteria; thus, the Fuzzy Analytical Hierarchy Process (FAHP) was applied for determining the weight of all potential suppliers, and the preference ranking organization method for enrichment of evaluations (PROMETHEE II) was used for ranking the supplier. The results of this research will assist researchers and decision makers in identifying, adapting and applying appropriate methods to identify the optimal material suppliers in the textile and garment industry. This research can also be used to support supplier selection decisions in other industries.
\end{abstract}

Keywords: fuzzy theory; sustainable development; SCOR model; FAHP; PROMETHEE II; textile and garments industry; sustainable supplier selection; MCDM

\section{Introduction}

At present, the textile and garment industry plays an increasingly important role in the national economy. It not only serves the increasing and diverse needs of the people but also creates many jobs and significantly contributes to the national budget to create conditions for economic development. In Vietnam, the textile and garment industry has made great strides. The average growth rate of the industry is about 30\%/year; in the export sector, the average growth rate is $24.8 \%$ /year and accounts for $20 \%$ of the country's total export turnover [1].

However, according to aggregate data of the Vietnam Textile and garment and Apparel Association (Vitas), the US-China trade conflict has made the total textile and garment demand on the world market 
increase by only $3.3 \%$ in 2019, compared to the up to $7.4 \%$ from the previous year [2]. When Vietnam joins the Trans-Pacific Strategic Partnership Agreement (TPP), textile and garment enterprises will enjoy a tax rate of $0 \%$. However, the TPP stipulates that all input materials of this industry must be from the TPP to be eligible for preferential tax rates, while Vietnam's textile and garment and garment industry is still heavily dependent on foreign material supply, accounting for nearly $88 \%$ of total demand; most of the countries where Vietnam imports raw materials are not part of the TPP [3]. Thus, raw materials supplier selection in a volatile competitive environment is crucial for a company to succeed.

The selection of material suppliers is an extremely important decision that can enhance a company's competitive advantage significantly by enabling the success of subsequence processes within the production chain. The main objective of a supplier selection process is to reduce purchasing risks, maximize overall value for buyers and develop proximity and long-term relationships between buyers and suppliers. Any supply chain activity begins with sourcing raw materials and ends with product delivery to consumers [4]. A perfect supply chain helps businesses gain many benefits, such as cost savings, competitive product prices. Therefore, choosing the right supplier plays an essential role in determining the success or failure in an organization [5]. Supplier selection is a multicriteria decision process and involves many quantitative and qualitative criteria. Thus, this study aims to develop a multicriteria decision making model (MCDM) for the supplier selection process within Vietnam textile and garments industry, by using the supply chain operations reference model (SCOR), Fuzzy Analytical Hierarchy Process (FAHP) and the preference ranking organization method for enrichment of evaluations (PROMETHEE II). The combination of these decision-making methods is an effective tool for supplier selection and evaluation [6,7].

The contribution of this study is to propose a multi-criteria decision-making model to use in supplier selection, which is considered a useful tool for companies operating to increase competitiveness and minimum production costs in the textile and garment industry.

\section{Literature Review}

As customers' expectations grow year after year, global companies are facing serious challenges in improving and optimizing their supply chains to satisfy consumers. These challenges are further increased with pressures from global competitions and the dissemination of enterprise information systems and shorter product life cycles, which lead to increasingly complex supply chains and requires more sophisticate management methods [8].

There are many different methods for identifying suppliers' criteria, assessments and selection that have been published in prestigious scientific journals. Govindan et al. [9] successfully applied a multi-criteria decision-making model in the evaluation and selection of environmentally-friendly suppliers. Therefore, it is possible to realize that the problem of supplier selection is an important topic in both scientific research and practical applications.

Choosing a supplier is a multifaceted strategic decision, but few studies have looked at factors such as sustainability and risks. Especially when the selection criteria are subjective and require the judgment of decision makers, and since for each supplier candidate a separate selection criterion dominates, the supplier selection process can become very complicate [10]. To address decision-related issues of sustainability, Multi Criteria Decision Analysis (MCDA) models are often applied to support the decision makers in these processes. However, from the methodological and practical perspective of sustainability assessment, the MCDA method has some shortcomings. To limit decision making errors, researchers have used more methods to reduce decision making errors, such as by combining the PROMETHEE and FAHP method [11,12]. Safari et al. [13] developed an integrated MCDM model for supplier evaluation and selection process. In this research, the weights of the evaluation criteria were determined using Shannon's Entropy, while PROMETHEE was used to rank the potential suppliers in the final stage. Senvar et al. [14] proposed a multi criteria supplier selection model based on a fuzzy 
PROMETHEE model. The proposed methodology can be used assist decision makers within supply chains in solving similar selection problems.

Chen et al. [15] presented a hybrid framework for third-party logistics service supplier selection process. The authors developed a hybrid decision making model by using linguistic PROMETHEE in combination with maximum deviation method to rank potential logistics service providers, based on criteria from industry experts, customers, and operational data. Dağdeviren [16] integrated an approach based on both AHP and PROMETHEE to solve an equipment selection problem. According to Pan et al. [17], multi-criteria decision-making (MCDM) has not been fully utilized to vendor selection processes. An approach based on AHP and PROMETHEE takes into account the characteristics of strategic sourcing, the index for selection focuses on cooperation and long-term character of suppliers and the method of supplier selection.

Bansal et al. [18] suggested that an AHP-PROMETHEE hybrid model is an effective tool for third-party logistics service supplier selection processes. AHP is employed to calculate the weights of criteria, whereas PROMETHEE ranks potential suppliers according to their performance based on these criteria. Shakey [19] introduced a hybrid AHP-PROMETHEE-2 multicriteria decision making model to support supplier selection processes. The result suggests that the hybrid model can calculate the optimum distribution of order quantities among the selected supplier, which maximizes total purchase value. Sari et al. [20] presented a plausible solution for complex selection problems, by comparing traditional and non-traditional methods. In this research, the authors identified a group of main criteria; including quality, delivery, price, environmental health, financial status, managerial capabilities and working conditions; then, they investigated their interrelations and determined each criterion importance degree. Wang et al. [21] applied a hybrid fuzzy analytical hierarchy process and green data envelopment analysis for the sustainable supplier selection process in edible oil production. Wang et al. [22] proposed an MCDM approach, including the fuzzy analytic network process (FANP) and The Technique for Order of Preference by Similarity to Ideal Solution (TOPSIS) model for solid waste to energy plant location selection in Vietnam. Wang et al. [23] applied the MCDM model for supplier selection in the rice supply chain.

As literature review shows, the amount of studies that have applied the MCDM approach to various fields of science and engineering has been increasing in number over the past years. Supplier selection is one of the fields where the MCDM model has been employed, especially in the garment and textile industry, where decision makers must evaluate both qualitative and quantitative factors. Although some studies have reviewed applications of MCDM approaches in garment supplier selection, very few works have focused on this problem in a fuzzy environment. This is a reason why we proposed a fuzzy MCDM model in this study.

\section{Methodology}

In this paper, the MCDM model for supplier selection is built through a number of steps, as shown in Figure 1.

\subsection{Theorical Basis}

\subsubsection{Supply Chain Operations Reference (SCOR) Model}

The problem of analyzing and assessing the current state of the selection process of the company needs to be identified. The criteria evaluated and used in the proposed model are built based on the SCOR model. The SCOR model, also known as the Supply Chain Operations Reference Model, was approved in 1996 and recognized by the Supply Chain Council (SCC) [24]. This model enables corporations to conduct a thorough analysis of their supply chains based on the information of various aspects of the supply chains by providing a set of process details and performance metrics.

As Theeranuphattana et al. [25] stated, the SCOR Model criteria set can be utilized as a business process reference model, providing a specific set of analysis tools for supply chain business processes, 
best practice metrics. The SCOR model is also an appropriate reference for industrial supply chains. Furthermore, the implementation of the SCOR model enables a common language between partners in a supply chain, as it standardizes definitions, process elements and metrics. The main performance attributes of the SCOR model are shown in Table 1.

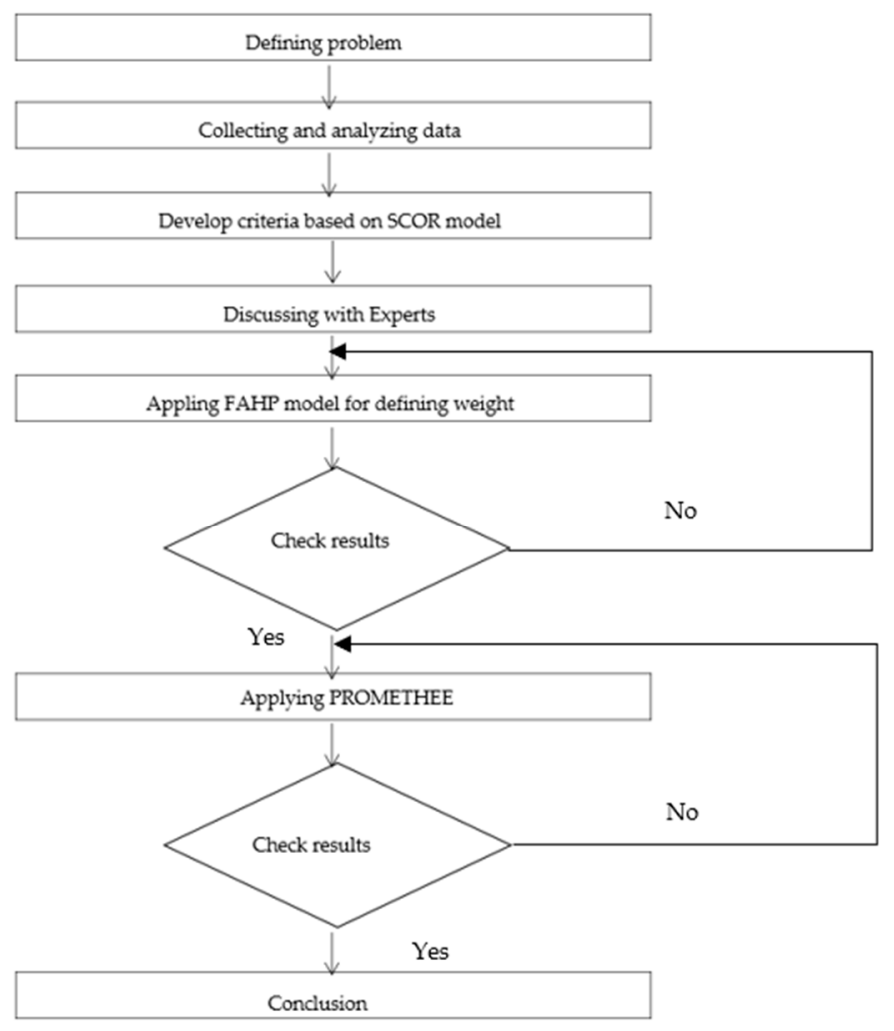

Figure 1. Research graph. SCOR: Supply Chain Operations Reference; FAHP: Fuzzy Analytical Hierarchy Process; PROMETHEE: preference ranking organization method for enrichment of evaluations.

Table 1. The performance attributes of the SCOR model.

\begin{tabular}{cl}
\hline Performance Attributes & \multicolumn{1}{c}{ Definition } \\
\hline Reliability & $\begin{array}{l}\text { Capable of fulfilling orders in the best way. With confidence, the focus is on the ability } \\
\text { to predict results. For example, delivery on time, high quality and appropriate quantity. }\end{array}$ \\
$\begin{array}{c}\text { Responsiveness } \\
\text { Flexibility }\end{array}$ & $\begin{array}{l}\text { Express the speed of execution of requests for customers. For example, cycle time. } \\
\text { Cost }\end{array}$ \\
Assets & $\begin{array}{l}\text { Costs include operating costs, particularly costs of materials, labor and transportation. } \\
\text { The ability to use financial resources effectively; being able to quickly execute requests } \\
\text { from customers. The ability to use funds, including inventory days and financial uses. }\end{array}$ \\
\hline
\end{tabular}

\subsubsection{Fuzzy Analytical Hierarchy Process (FAHP)}

AHP is a Multiple Criteria Decision Making (MCDM) method that simplifies complex and unclear structured issues by using pairwise comparison matrix to sort criteria [24]. AHP has the main advantage of ranking alternatives in order of effectiveness.

In the AHP model, there are many pairwise comparison metric assembled based on the nine levels of the standardized comparison scale [24]. The AHP method is applied to select the priority level at all levels of the hierarchy according to the pairwise comparison matrix, measured using a scale of 1 to 9 [24].

The Analytical Hierarchy Process, which uses fuzzy theory, is further developed based on AHP. In 1965, Zadeh proposed a theory for use in uncertain environmental conditions [25]. With the application of fuzzy set theory, it can help us better understand and better estimate uncertainty. The degree of dependence of a fuzzy number on certain sets are shown using a fuzzy set. The value of 
the member function is within the range $[0 ; 1][26,27]$. The Triangular Fuzzy Number (TFN) can be defined as $(\mathrm{o}, \mathrm{g}, \mathrm{p})$, respectively, with $\mathrm{o}, \mathrm{g}$ and $\mathrm{p}(\mathrm{o} \leq \mathrm{g} \leq \mathrm{p})$ as parameters, indicating the smallest, most promising TFN and corresponding maximum values. Each degree of membership includes $\boldsymbol{M}^{o(y)}$ (left) and $\boldsymbol{M}^{i(y)}$ (right), which represent the two sides of a fuzzy number:

$$
\widetilde{M}=\left(\boldsymbol{M}^{o(y)}, \boldsymbol{M}^{i(y)}\right)=[\mathbf{o}+(\mathbf{g}-\mathbf{o}) \mathbf{y}, \mathbf{p}+(\mathbf{g}-\mathbf{p}) \boldsymbol{y}], y \in[\mathbf{0}, \mathbf{1}]
$$

TFN is shown in Figure 2.

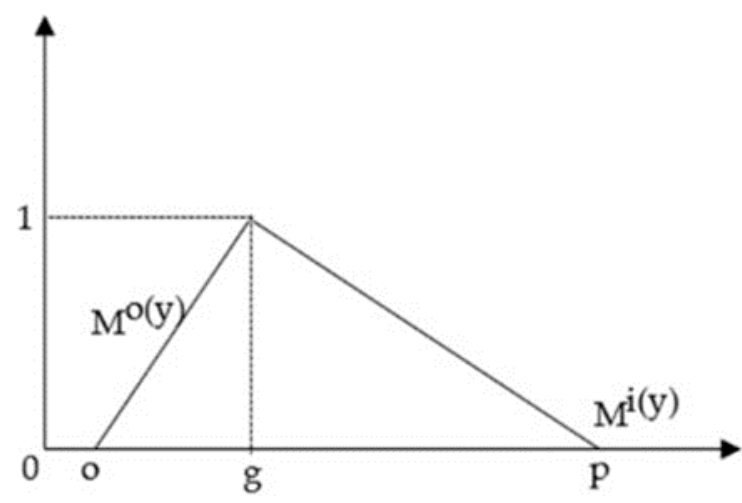

Figure 2. Triangular Fuzzy Number.

\subsubsection{Preference Ranking Organization Method for Enrichment of Evaluations (PROMETHEE)}

Preference ranking organization method for enrichment of evaluations (PROMETHEE) was introduced by Brans and Vincke in 1985 [28]. PROMETHEE I can enable a partial review of alternative decisions, while PROMETHEE II can evaluate the overall rankings of the alternatives. In this research, the PROMETHEE II was utilized to calculate the ranking of potential suppliers. PROMETHEE II was performed according to these followed steps [29,30]:

Step 1: Normalize the decision matrix:

$$
R_{i j}=\frac{\left[x_{i j}-\min \left(x_{i j}\right)\right]}{\left[\max \left(x_{i j}\right)-\min \left(x_{i j}\right)\right]} .
$$

where $x_{i j}$ is the performance indicator of the $i^{\text {th }}$ alternative with reference to the $j^{\text {th }}$ criterion. For non-beneficial criteria, Equation (1) can be rearranged as follows:

$$
R_{i j}=\frac{\left[\max \left(x_{i j}\right)-x_{i j}\right]}{\left[\max \left(x_{i j}\right)-\min \left(x_{i j}\right)\right]} .
$$

Step 2: Determine the differences of the $i^{\text {th }}$ alternative in comparison to other alternatives by calculating the pairwise differences in criteria values between the alternatives

Step 3: Determine the preference function, $P_{j}\left(i, i^{\prime}\right)$. Bran and Mareschal [21] proposed six main type of generalized reference functions [28]. However, these functions require some preferential parameters to be well defined, which, in real world cases, may cause unnecessary difficulties and complexities to the decision makers. Therefore, a simplified preference function is adopted in this study:

$$
\begin{gathered}
\boldsymbol{P}_{j}\left(i, i^{\prime}\right)=0 \text { if } \boldsymbol{R}_{i j} \leq \boldsymbol{R}_{i^{\prime} j}, \\
\boldsymbol{P}_{j}\left(i, i^{\prime}\right)=\left(\boldsymbol{R}_{i j}, \boldsymbol{R}_{i^{\prime} j}\right) \text { if } \boldsymbol{R}_{i j}>\boldsymbol{R}_{i^{\prime} j}
\end{gathered}
$$


Step 4: Determine the aggregated preference function with respect to the weights of the criteria. The aggregated preference function is as follows:

$$
\pi\left(i, i^{\prime}\right)=\frac{\left[\sum_{j-1}^{m} w_{j} \times p_{j\left(i, i^{\prime}\right)}\right]}{\sum_{j-1}^{m} w_{j} \times p_{j\left(i, i^{\prime}\right)}} .
$$

where $w_{j}$ is the weight of the $j_{t h}$ criterion.

Step 5: Calculate the leaving and entering outranking flows:

$$
\begin{gathered}
\Phi^{+}(i)=\frac{1}{n-1} \times \sum_{i^{\prime}=1}^{n} \pi\left(i, i^{\prime}\right) \text { with } i \neq i^{\prime} \\
\Phi^{-}(i)=\frac{1}{n-1} \times \sum_{i^{\prime}=1}^{n} \pi\left(i^{\prime}, i\right) \text { with } i \neq i^{\prime} .
\end{gathered}
$$

where $n$ is the number of alternatives.

In this step, each alternative is compared with $(\boldsymbol{n}-\mathbf{1})$ other alternatives. The leaving flow shows how much the alternative outranks others, whereas the entering flow show how much the alternative is outranked by others. Then, a partial preorder of the alternative can be obtained using PROMETHEE I, or, a complete preorder can be obtained using PROMETHEE II by using a net flow. However, using PROMETHEE II can lead to loss of preference relations information.

Step 6: Determine the net outranking flow for individual alternative:

$$
\Phi(i)=\Phi^{+}(i)-\Phi^{-}(i) .
$$

Step 7: Calculate the ranking of all potential alternatives based the value of $\Phi(i)$. The higher value of $\boldsymbol{\Phi}(\boldsymbol{i})$, the better is the alternative. Thus, the best alternative is the one with the highest $\boldsymbol{\Phi}(\boldsymbol{i})$ value.

\section{Case Study}

Vietnam's textile and garment in the international market is said to be currently competitive because of its abundant labor force, high skilled skills and low labor costs when compared to the productivity. However, facing these advantages, Vietnam's textile and garment and garment industry in 2020, besides opportunities and prospects, still faces significant challenges in selecting raw material suppliers. In addition to the tax reduction in the provisions of the EVFTA Agreement, Vietnam's textile and garment products must comply closely with the standards committed in the Agreement such as standards of the origin of raw materials. Thus, the purpose of selecting the right supplier is to improve a company's competitiveness and product quality, while satisfying customer demand at a lower cost.

This study aimed to develop a multicriteria decision making model (MCDM) for the supplier selection process within the Vietnam textile and garments industry, by using the supply chain operations reference model (SCOR), Fuzzy Analytical Hierarchy Process (FAHP) and the preference ranking organization method for enrichment of evaluations (PROMETHEE II). To verify the proposed model, the model will be used to select an optimal supplier from 10 potential suppliers, which is provided by industry experts and head of the purchasing department of a Vietnamese textile company. Ten industry experts were consulted and interviewed to obtain suitable criteria for the model. All criteria affecting to supplier selection process are show in Table 2. 
Table 2. Criteria for evaluating supplier define based on the SCOR model.

\begin{tabular}{|c|c|c|c|}
\hline No. & Main Criteria & Sub-Criteria & Symbol \\
\hline \multirow{3}{*}{1} & \multirow{3}{*}{ Reliability (A) } & Delivered the right quantity & A1 \\
\hline & & Fulfill an order request & A2 \\
\hline & & Delivery performance & A3 \\
\hline \multirow{3}{*}{2} & \multirow{3}{*}{ Responsiveness (B) } & Order Fulfillment Cycle Time & B1 \\
\hline & & Delivery time & B2 \\
\hline & & Return processing time & B3 \\
\hline \multirow{2}{*}{3} & \multirow{2}{*}{ Flexibility (C) } & Order fulfillment lead time & $\mathrm{C} 1$ \\
\hline & & Production flexibility & $\mathrm{C} 2$ \\
\hline \multirow{3}{*}{4} & \multirow{3}{*}{ Cost (D) } & Transportation cost & D1 \\
\hline & & Returns processing cost & D2 \\
\hline & & Materials cost & D3 \\
\hline \multirow{4}{*}{5} & \multirow{4}{*}{ Assets (E) } & Cash to cash cycle time & E1 \\
\hline & & Asset turns & E2 \\
\hline & & Inventory days of supply & E3 \\
\hline & & Inventory value & $\mathrm{E} 4$ \\
\hline
\end{tabular}

The industry experts also discussed and provided their inputs based on a 1-9 Saaty scale (Table 3).

Table 3. 1-9 Saaty Scale of Importance Intensities.

\begin{tabular}{cl}
\hline Importance Intensity & \multicolumn{1}{c}{ Definition } \\
\hline 1 & Equal importance \\
3 & Moderate importance of one over another \\
5 & Essential importance \\
7 & Demonstrated importance \\
9 & Extremely importance \\
$2,4,6,8$ & Intermediate values \\
\hline
\end{tabular}

Based on the inputs from the consulted industry experts, the fuzzy comparison matrix of the main criteria from the AHP model are calculated as in Table 4.

Table 4. Fuzzy comparison matrix for the main criteria.

\begin{tabular}{cccccc}
\hline Main Criteria & A & B & C & D & E \\
\hline A & $(1,1,1)$ & $(1,2,3)$ & $(1 / 5,1 / 4,1 / 3)$ & $(1 / 4,1 / 3,1 / 2)$ & $(1,2,3)$ \\
\hline B & $(1 / 3,1 / 2,1 / 1)$ & $(1,1,1)$ & $(1 / 3,1 / 2,1 / 1)$ & $(1 / 4,1 / 3,1 / 2)$ & $(1,2,3)$ \\
\hline C & $(3,4,5)$ & $(1,2,3)$ & $(1,1,1)$ & $(1,2,3)$ & $(2,3,4)$ \\
\hline D & $(2,3,4)$ & $(2,3,4)$ & $(1 / 3,1 / 2,1 / 1)$ & $(1,1,1)$ & $(3,4,5)$ \\
\hline E & $(1 / 3,1 / 2,1 / 1)$ & $(1 / 3,1 / 2,1 / 1)$ & $(1 / 4,1 / 3,1 / 2)$ & $(1 / 5,1 / 4,1 / 3)$ & $(1,1,1)$ \\
\hline
\end{tabular}

The values in Table 5 were converted to real numbers by using the TFN. During the defuzzification, the authors obtained the coefficients $\alpha=0.5$ and $\beta=0.5$. Here, $\alpha$ represents the uncertain environment conditions, and $\beta$ represents the attitude of the evaluator is fair. 
Table 5. Real number priority of the main criteria.

\begin{tabular}{cccccc}
\hline Main Criteria & A & B & C & D & E \\
\hline A & 1 & 2 & $1 / 4$ & $1 / 3$ & 2 \\
\hline B & $1 / 2$ & 1 & $1 / 2$ & $1 / 3$ & 2 \\
\hline C & 4 & 2 & 1 & 2 & 3 \\
\hline D & 3 & 3 & $1 / 2$ & 1 & 4 \\
\hline E & $1 / 2$ & $1 / 2$ & $1 / 3$ & $1 / 4$ & 1 \\
\hline
\end{tabular}

The individual maximum value $\lambda_{\max }$ and weight $w$ of the matrix are calculated as follows:

$$
\begin{gathered}
\text { GM1 }=\left(1 \times 2 \times \frac{1}{4} \times \frac{1}{3} \times 2\right)^{\frac{1}{5}}=0.8 \\
\text { GM2 }=\left(\frac{1}{2} \times 1 \times \frac{1}{2} \times \frac{1}{3} \times 2\right)^{\frac{1}{5}}=0.7 \\
\text { GM3 }=(4 \times 2 \times 1 \times 2 \times 3)^{\frac{1}{5}}=2.17 \\
\text { GM4 }=\left(3 \times 3 \times \frac{1}{2} \times 1 \times 4\right)^{\frac{1}{5}}=1.78 \\
\text { GM5 }=\left(\frac{1}{2} \times \frac{1}{2} \times \frac{1}{3} \times \frac{1}{4} \times 1\right)^{\frac{1}{5}}=0.46 \\
\sum G M=5.91
\end{gathered}
$$

The weights of individual main criteria are calculated as follows:

$$
\begin{aligned}
& \omega_{1}=\frac{0.8027}{5.9140}=0.14 \\
& \omega_{2}=\frac{0.6988}{5.9140}=0.12 \\
& \omega_{3}=\frac{2.6189}{5.9140}=0.37 \\
& \omega_{4}=\frac{1.7826}{5.9140}=0.3 \\
& \omega_{5}=\frac{0.4610}{5.9140}=0.08 \\
& {\left[\begin{array}{ccccc}
1 & 2 & 1 / 4 & 1 / 3 & 2 \\
1 / 2 & 1 & 1 / 2 & 1 / 3 & 2 \\
4 & 2 & 1 & 2 & 3 \\
3 & 3 & 1 / 2 & 1 & 4 \\
1 / 2 & 1 / 2 & 1 / 3 & 1 / 4 & 1
\end{array}\right] x\left[\begin{array}{l}
0.14 \\
0.12 \\
0.37 \\
0.30 \\
0.08
\end{array}\right]=\left[\begin{array}{c}
0.72 \\
0.63 \\
1.98 \\
1.56 \\
0.40
\end{array}\right]} \\
& {\left[\begin{array}{l}
0.72 \\
0.63 \\
1.98 \\
1.56 \\
0.40
\end{array}\right] /\left[\begin{array}{l}
0.14 \\
0.12 \\
0.37 \\
0.30 \\
0.08
\end{array}\right]=\left[\begin{array}{l}
5.30 \\
5.30 \\
5.41 \\
5.17 \\
5.16
\end{array}\right]}
\end{aligned}
$$


Based on number of main criteria, the authors found that $n=5 ; \lambda_{\text {max }}$ and CI are calculated as follows:

$$
\begin{gathered}
\lambda_{\max }=\frac{5.30+5.30+5.41+5.17+5.16}{5}=5.27 \\
C I=\frac{\lambda_{\max }-n}{n-1}=\frac{5.27-5}{5-1}=0.07
\end{gathered}
$$

To calculate the CR value, we found that $\mathrm{RI}=1.12$, with $n=5$.

$$
C R=\frac{C I}{R I}=\frac{0.07}{1.12}=0.06
$$

Since $C R=0.06 \leq 0.1$, there is no need to re-evaluate. The weights of the main criteria are shown in Table 6.

Table 6. The weights of the main criteria.

\begin{tabular}{ccccccc}
\hline Main Criteria & A & B & C & D & E & Weight \\
\hline A & 1 & 2 & $1 / 4$ & $1 / 3$ & 2 & 0.14 \\
\hline B & $1 / 2$ & 1 & $1 / 2$ & $1 / 3$ & 2 & 0.12 \\
\hline C & 4 & 2 & 1 & 2 & 3 & 0.37 \\
\hline D & 3 & 3 & $1 / 2$ & 1 & 4 & 0.30 \\
\hline E & $1 / 2$ & $1 / 2$ & $1 / 3$ & $1 / 4$ & 1 & 0.08 \\
\hline \multicolumn{7}{c}{ Total } \\
\hline \multicolumn{7}{c}{ CR $=0.06$} \\
\hline
\end{tabular}

The weight of each sub criteria can be calculated based on the weights of main criteria. The calculated weight of each sub criteria using FAHP is shown in Table 7.

Table 7. The weight of the sub criteria.

\begin{tabular}{ccc}
\hline No & Symbol & Weight \\
\hline 1 & A1 & 0.07 \\
\hline 2 & A2 & 0.05 \\
\hline 3 & A3 & 0.01 \\
\hline 4 & B1 & 0.08 \\
\hline 5 & B2 & 0.03 \\
\hline 6 & B3 & 0.01 \\
\hline 7 & C1 & 0.28 \\
\hline 8 & C2 & 0.09 \\
\hline 9 & D1 & 0.22 \\
\hline 10 & D2 & 0.06 \\
\hline 11 & D3 & 0.02 \\
\hline 12 & E1 & 0.05 \\
\hline 13 & E2 & 0.00 \\
\hline 14 & E3 & 0.02 \\
\hline 15 & E4 & 0.01 \\
\hline
\end{tabular}

In the next stage, PROMETHEE II was implemented to evaluate and rank the potential suppliers. The results of PROMETHEE II is shown in Table 8. 
Table 8. Final ranking from PROMETHEE II.

\begin{tabular}{ccccc}
\hline Supplier & $\boldsymbol{\Phi}^{+}(\mathbf{i})$ & $\boldsymbol{\Phi}^{-}(\mathbf{i})$ & $\boldsymbol{\Phi}(\mathbf{i})$ & Ranking \\
\hline $\mathbf{S 1}$ & 1.46 & 2.2 & -0.74 & 8 \\
\hline S2 & 1.04 & 2.99 & -1.95 & 10 \\
\hline S3 & 2.23 & 1.75 & 0.48 & 5 \\
\hline S4 & 1.94 & 2.55 & -0.61 & 7 \\
\hline S5 & 2.25 & 1.71 & 0.54 & 4 \\
\hline S6 & 1.41 & 1.96 & -0.55 & 6 \\
\hline S7 & 1.68 & 2.49 & -0.81 & 9 \\
\hline S8 & 2.27 & 1.32 & 0.95 & $\mathbf{1}$ \\
\hline S9 & $\mathbf{2 . 8 2}$ & $\mathbf{1 . 3 3}$ & $\mathbf{1 . 4 9}$ & 2 \\
\hline S10 & 2.58 & 1.38 & 1.20 &
\end{tabular}

\section{Discussion}

Textile enterprises have started to spend a large amount of investment in modern technologies to catch up with the trend of Industry 4.0. There have been many factories investing in public equipment modern technology and robots. Enterprises have been providing solutions to change the product structure and promote exports of high value goods. The selection of material suppliers is an extremely important decision that can enhance a company's competitive advantage significantly by enabling the success of subsequence processes within the production chain. The main objective of a supplier selection process is to reduce purchasing risks, maximize overall value for buyers and develop proximity and long-term relationships between buyers and suppliers.

In this paper, the proposed model was built through three phases as described in Section 3. In the first stage, all criteria affecting to raw material are defined based on SCOR model. FAHP was applied to evaluate weights for the criteria. In the second stage, the criteria will be assessed on a fuzzy scale through experts in the textile and garment industry. In final stage, the authors continue to apply the PROMETHEE II method to enrich the selection, rank the suppliers and help select the most appropriate supplier. Based on the results of PROMETHEE II presented in Table 8, supplier ranking list is S9, S10, S8, S5, S3, S6, S4, S1, S7 and finally S2. With the above results, we can determine that the optimal supplier is supplier 9 (S9).

\section{Conclusions}

In modern supply chains, supplier performance is evaluated using multiple criteria rather than just cost factors. The selection optimal suppliers nowadays incorporate new viewpoints towards better resource allocation, minimizing risks associated with purchasing and reducing costs by saving time, money and effort.

In this study, the authors proposed a multi-criteria decision-making model for supplier selection in the textile industry in Vietnam. SCOR model helps to build a set of criteria, as a prerequisite for the next stage, using the FAHP model to determine the weight of these criteria. Finally, PROMETHEE II provided the ranking of potential suppliers and identified the optimal alternative. PROMETHEE II helped utilizing the exact weight set of FAHP after converting fuzzy numbers, while reducing the subjectivity of the assessor when developing the FAHP model. In addition, PROMETHEE II is easy to understand, easy to perform calculations and give clear results. Quantitative research also helps to model, analyze data and statistics and produce clear results.

The research has implemented SCOR, FAHP and PROMETHEE II models for selecting the most suitable supplier and the implementation using a case study has shown that the proposed model is feasible. However, while the proposed model provides important criteria for supplier selection 
processes in garment and textile industry, decision makers can alter the number of criteria to better fit their organizations' specific needs and situations.

The combined model can also be studied in conjunction with other models to diversify options. Not only that, this research can also be applied to many other fields such as financial assessment and measuring the level of risk in construction engineering.

Author Contributions: Conceptualization, C.-N.W., V.T.H.V, T.P.H., V.T.N. (Van Thanh Nguyen) and V.T.N. (Viet Tinh Nguyen); Data curation, C.-N.W., V.T.H.V., V.T.N. (Van Thanh Nguyen) and V.T.N. (Viet Tinh Nguyen); Formal analysis, T.P.H. and V.T.N. (Viet Tinh Nguyen); Funding acquisition, V.T.H.V., T.P.H., V.T.N. (Van Thanh Nguyen) and V.T.N. (Viet Tinh Nguyen); Investigation, C.-N.W., V.T.H.V. and V.T.N. (Viet Tinh Nguyen); Methodology, C.-N.W., V.T.H.V., T.P.H., V.T.N. (Van Thanh Nguyen) and V.T.N. (Viet Tinh Nguyen); Project administration, T.P.H., V.T.N. (Van Thanh Nguyen) and V.T.N. (Viet Tinh Nguyen); Resources, C.-N.W.; Software, V.T.N. (Van Thanh Nguyen); Validation, V.T.N. (Van Thanh Nguyen); Visualization, T.P.H.; Writing-original draft, V.T.H.V. and V.T.N. (Viet Tinh Nguyen); Writing-review and editing, C.-N.W., T.P.H. and V.T.N. (Van Thanh Nguyen). All authors have read and agreed to the published version of the manuscript.

Funding: This research was partly supported by National Kaohsiung University of Science and Technology, and project number 108-2622-E-992-017-CC3 from the Ministry of Sciences and Technology in Taiwan.

Acknowledgments: The authors appreciate the support from Taiwan National Kaohsiung University of Science and Technology, Philippines Technological University of the Philippines Taguig, and Taiwan Ministry of Sciences and Technology.

Conflicts of Interest: The authors declare no conflict of interest.

\section{References}

1. Nhu, H. Khái quát về xuất khẩu hàng dệt may ở Việt Nam và vai trò của nó đối với nền kinh tế. Available online: https://voer.edu.vn/m/khai-quat-ve-xuat-khau-hang-det-may-o-viet-nam-va-vai-tro-cuano-doi-voi-nen-kinh-te/ebe05f9f (accessed on 12 March 2020).

2. Luu, D. Dệt may Việt Nam trông chờ tín hiệu sáng 2020. Available online: https://tinnhanhchungkhoan.vn/ thuong-truong/det-may-viet-nam-trong-cho-tin-hieu-sang-2020-308761.html (accessed on 12 March 2020).

3. Nang, D. Ngành dệt may sẽ gặp khó khăn khi Việt Nam tham gia TPP. Available online: http://www.hoatho. com.vn/tin-tuc/thong-tin-trong-nganh/nganh-det-may-se-gap-kho-khan-khi-viet-nam-tham-gia-tpp (accessed on 12 March 2020).

4. Gencer, C.; Gürpinar, D. Analytic network process in supplier selection: A case study in an electronic firm. Appl. Math. Model. 2007, 31, 2475-2486. [CrossRef]

5. Rouyendegh, B.D.; Erol, S. The dea-Fuzzy anp department ranking model applied in iran amirkabir university. Acta Polytech. Hung. 2010, 7, 103-114.

6. Taherdoost, H.; Brard, A. Analyzing the process of supplier selection criteria and methods. Procedia Manuf. 2019, 32, 1024-1034. [CrossRef]

7. Gul, M.; Guven, B.; Guneri, A.F. A new Fine-Kinney-based risk assessment framework using FAHP-FVIKOR incorporation. J. Loss Prev. Process Ind. 2018, 53, 3-16. [CrossRef]

8. Yu, X.; Chen, H.; Ji, Z. Combination of probabilistic linguistic term sets and PROMETHEE to evaluate meteorological disaster risk: Case study of southeastern China. Sustainability 2019, 11, 1405. [CrossRef]

9. Govindan, K.; Rajendran, S.; Sarkis, J.; Murugesan, P. Multi criteria decision making approaches for green supplier evaluation and selection: A literature review. J. Clean. Prod. 2015, 98, 66-83. [CrossRef]

10. Alikhani, R.; Torabi, S.A.; Altay, N. Strategic supplier selection under sustainability and risk criteria. Int. J. Prod. Econ. 2019, 208, 69-82. [CrossRef]

11. Liao, H.; Wu, D.; Huang, Y.; Ren, P.; Xu, Z.; Verma, M. Green logistic provider selection with a hesitant fuzzy linguistic thermodynamic method integrating cumulative prospect theory and PROMETHEE. Sustainability 2018, 10, 1291. [CrossRef]

12. Wang, C.N.; Huang, Y.F.; Cheng, I.; Nguyen, V.T. A multi-criteria decision-making (MCDM) approach using hybrid SCOR metrics, AHP, and TOPSIS for supplier evaluation and selection in the gas and oil industry. Processes 2018, 6, 252. [CrossRef]

13. Safari, H.; Fagheyi, M.S.; Ahangari, S.S.; Fathi, M.R. Applying PROMETHEE method based on entropy weight for supplier selection. Bus. Manag. Strategy 2012, 3, 97-106. [CrossRef] 
14. Senvar, O.; Tuzkaya, G.; Kahraman, C. Multi Citeria Supplier Selection Using Fuzzy PROMETHEE Method. In Supply Chain Management under Fuzziness; Springer: Berlin/Heidelberg, Germany, 2014; pp. 21-34.

15. Chen, C.T.; Pai, P.F.; Hung, W.Z. An integrated methodology using linguistic PROMETHEE and maximum deviation method for third-party logistics supplier selection. Int. J. Comput. Intell. Syst. 2010, 3, 438-451. [CrossRef]

16. Dağdeviren, M. Decision making in equipment selection: An integrated approach with AHP and PROMETHEE. J. Intell. Manuf. 2008, 19, 397-406. [CrossRef]

17. Pan, W.H.; Li, J.Q. Application of AHP-PROMETHEE Method for Supplier Selection in Strategic Sourcing. Oper. Res. Manag. Sci. 2009, 2, 008.

18. Bansal, A.; Kumar, P. 3PL selection using hybrid model of AHP-PROMETHEE. Int. J. Serv. Oper. Manag. 2013, 14, 373-397. [CrossRef]

19. Shakey, B.K. Supplier selection using AHP and promethee-2. Int. J. Sci. Res. 2006, 6, 156-160. [CrossRef]

20. Sari, T.; Timor, M. Integrated supplier selection model using ANP, Taguchi loss function and PROMETHEE methods. J. Appl. Quant. Methods 2016, 11, 19-34.

21. Brans, J.; Vincke, P.; Mareschal, B. How to select and how to rank projects: The Promethee method. Eur. J. Oper. Res. 1986, 24, 228-238. [CrossRef]

22. Wang, C.N.; Nguyen, V.T.; Duong, D.H.; Thai, H.T.N. A hybrid fuzzy analysis network process (FANP) and the technique for order of preference by similarity to ideal solution (TOPSIS) approaches for solid waste to energy plant location selection in Vietnam. Appl. Sci. 2018, 8, 1100. [CrossRef]

23. Wang, C.N.; Nguyen, V.T.; Duong, D.H.; Do, H.T. A hybrid fuzzy analytic network process (FANP) and data envelopment analysis (DEA) approach for supplier evaluation and selection in the rice supply chain. Symmetry 2018, 10, 221. [CrossRef]

24. Jamehshooran, B.G.; Shaharoun, M.; Haron, H.N. Assessing supply chain performance through applying the SCOR model. Int. J. Supply Chain Manag. 2015, 4, 1-11.

25. Theeranuphattana, A.; Tang, J.C. A conceptual model of performance measurement for supply chains. J. Manuf. Technol. Manag. 2008, 7, 41. [CrossRef]

26. Rezaie, K.; Byat, M.; Shirkouhi, S.N. Evaluating effective factors of implementing knowledge management based on FAHP method. In Proceedings of the IEEE 2009 Third Asia International Conference on Modelling \& Simulation, Bali, Indonesia, 25-29 May 2009; pp. 398-403.

27. Wang, C.-N.; Nguyen, V.T.; Thai, H.T.N.; Duong, D.H. Multi-Criteria Decision Making (MCDM) Approaches for Solar Power Plant Location Selection in Viet Nam. Energies 2018, 11, 1504. [CrossRef]

28. Brans, J.; Vincke, P. A Preference Ranking Organisation Method (The PROMETHEE Method for Multiple Criteria Decision-Making). Manag. Sci. 1985, 31, 647-656. [CrossRef]

29. Ningsih, S.R.; Windarto, A.P. Penerapan Metode Promethee II Pada Dosen Penerima Hibah P2M Internal. InfoTekJar: Jurnal Nasional Informatika dan Teknologi Jaringan 2018, 3, 20-25. [CrossRef]

30. Adelia, F.; Wahyuli, D.; Sari, T.I.; Windarto, A.P. Analisis Promethee II Pada Faktor Penyebab Mahasiswa Sulit Menemukan Judul Artikel Ilmiah. Jurnal Ilmiah KOMPUTASI 2018, 17, 131-136.

(C) 2020 by the authors. Licensee MDPI, Basel, Switzerland. This article is an open access article distributed under the terms and conditions of the Creative Commons Attribution (CC BY) license (http://creativecommons.org/licenses/by/4.0/). 